\title{
Review of Johan J. Graafland's The market, happiness, and solidarity: a Christian perspective. London/New York: Routledge, 2010, 186 pp.
}

\author{
JOOST W. HENGSTMENGEL \\ EIPE, Erasmus University Rotterdam
}

Christian economics has always had a love-hate relationship to the market. Some Christian economists consider the market mechanism as a manifestation of God's providence and defend it as a divine solution, for example, to poverty; whereas others portray it as a modern idol and point to its sinful and destructive side-effects. Outsiders may find it puzzling that Christian economists can be found supporting capitalism, socialism, and communism alike. However, the fact that Christian economics has many faces is less surprising when we recognize that the Bible, Christian tradition, and Christian theology all take an ambivalent attitude towards "the economic" in general. To give some examples, Job's loyalty to God was rewarded by making him rich; Christ preached that it is easier for a camel to pass through the eye of a needle than for a rich man to enter into the Kingdom of God; Augustine stated that there can be no sinfulness in trade but only in the trader; and Aquinas argued that to demand interest for lending money is unjust. From a Christian point of view, in short, economic success can be a curse as well as a blessing. "It all depends". And the same holds true for the market, as Johan Graafland shows in his new book.

The primary aim of The market, happiness, and solidarity (a translation and revision of Graafland 2007b) is to clarify the links between ethical values, Christian belief, and economics. More specifically Graafland, a professor of economics, business, and ethics at Tilburg University in the Netherlands, tries to contribute to the Christian debate about the market, market operations, and the market economy by formulating a Christian perspective on it. In this perspective three disciplines are combined, namely economics, ethics, and theology. Although the revision thus complements Graafland's book (2007a) with a theological dimension, it is still ethically rather than theologically orientated. The core chapters examine the effects of the market on three more or less ethical issues, to wit welfare or happiness, justice, and 
virtue. The point is that for the author "[t]he link between Christian faith and economics is ethics" (p. 9). Ethics is, in other words, where Christian faith and economics meet and a Christian perspective on the market is in the end an ethical perspective.

Before discussing the three ethical perspectives on the market in somewhat more detail, it is useful to hold the methodology of the book up to the light. Why, first of all, does it focus on welfare or happiness, justice, and virtue? According to the author, these are three typical "effects" of the market about which its defenders and critics disagree. Some economists and politicians claim that the market has positive effects on welfare or happiness, contributes to justice, and reinforces virtues, whereas others argue the opposite. The reason for this disagreement is not only that scientific knowledge of the effects of the market is scarce (the positive aspect), but also that economists and politicians have different value orientations with respect to the market, i.e., different views on which values it should serve and how it in practice contributes to the realization of these values (the normative aspect). A Christian view of the market, Graafland argues, should therefore "link biblical teaching on the economy with recent theoretical and empirical research" (p. 9) and this is indeed what the book does. However, such a view is not only based on theology and this is reflected in the way the chapters are organized. In each of them, firstly some relevant "secular" ethical theories are discussed; secondly these are confronted with a Christian ethical account of the topic; thirdly an overview of current theoretical and empirical economic knowledge is provided to prevent "economic illiteracy"; and finally a Christian view is formulated by evaluating and relating the foregoing findings. A Christian view of the market, in other words, combines secular ethics, Christian ethics, and economic research.

The word "biblical" instead of "Christian" in the above quotation betrays Graafland's consistently Protestant approach. In fact, the terms Bible, theology, and Christian faith are taken as more or less synonymous. However, Graafland's Christian view of the market is not based on the theological or church tradition, but merely derives principles on welfare, justice, and virtue from the Bible, whereas the book's subtitle "a Christian perspective" suggests something broader. ${ }^{1}$ It is true, the author acknowledges, that the Bible is not a handbook of economics and ethics, and he sometimes relies on Calvin and

\footnotetext{
${ }^{1}$ But certainly not "a Christmas perspective", as an unfortunate typo puts it on p. xii.
} 
contemporary Christian economists, but still this Protestant approach is a clear limitation of the book.

In the first chapter, after the introduction in which methodological questions are discussed, Graafland examines whether or not the market creates welfare and contributes to happiness. He argues that the market economy under certain conditions, namely the right mixture of neoclassical, neo-Austrian, and Keynesian elements, at least fosters economic growth, which does not eliminate scarcity but does generally make people happier. Also from a Christian perspective, economic growth can be defended as it creates employment and helps to fight poverty. Instead of a stationary "economy of sufficiency", as proposed by the influential Dutch Christian economist Bob Goudzwaard, a concept of selective growth is to be preferred. That is to say, economic growth should be directed at serving real human needs, for example the reduction of poverty. The biblical ideal in this respect, the author states in an interesting section, is moderate scarcity. Whereas the complete abolition of scarcity and restrictions on human needs could be "the gateway to hell", a situation of moderate scarcity still requires our use of talents, creativity, and power in order to meet our responsibilities towards our fellow humans and the environment. Graafland concludes that "the perfect free market is a beautiful and inspiring ideal" (p. 54) that requires good government intervention to function well in reality.

The second chapter considers how the market relates to principles of right and justice. Graafland introduces twelve principles of distributive justice in ethics, including the theories of Robert Nozick, John Rawls, and Amartya Sen, and shows that several of them are supported by the Bible too. This means that egalitarian as well as capitalist or libertarian views on justice are promoted in different biblical contexts. The fact that secular ethics and Christian ethics often resemble each other is not surprising, since the former has been influenced by the latter and vice versa, something the author recognizes. Economic research shows that well-functioning markets without severe market imperfections and too intensive competition can indeed respect both positive and negative types of justice. Typical of a Christian view on the market and justice is the priority of the poor. Governments of Western countries should not only give priority to meeting the basic needs of their own citizens and therefore to a certain degree redistribute income, but also play an active role in the development process of poor countries. At the same time, "the range of income 
inequality that is still legitimate from a Christian point of view is quite large" (p. 94).

In the penultimate chapter, Graafland examines whether the market strengthens or excludes virtues, and especially Christian virtues like faith, hope and love. Graafland here tries to follow up Albert Hirschman's discussion (1982) of the doux commerce versus the self-destruction thesis, i.e., the question of whether commerce and competition have a favourable impact on human manners and virtues overall or just undermine them. Graafland starts by discussing and relating the classical virtue ethics of Aristotle and the biblical virtues and vices, which again partly overlap. He then brings in empirical research to analyze the effects of market operations on both classical and Christian virtues. The problem with this virtue ethical perspective on the market, however, is that little empirical research has been done, possibly because this relationship is so un-amenable to measurement. As a result, the results of existing (theoretical) economic research are often vague, conflicting, or at the least uncertain. This renders the chapter somewhat ineffective. Nevertheless, Graafland here brings together an extensive literature on the relationship between the market and a variety of virtues, which is valuable in itself. His conclusion is that there may be a curvilinear relationship between competition and virtues, so that whether the market will erode virtues or reinforce them depends, among other things, on the degree of competition. Whereas a moderate form of competition has a healthy impact on virtues, a lack of competition as well as fierce competition will be destructive. The same, he argues, holds true for Christian virtues. Especially because fierce competition may erode its most central virtue, namely the virtue of love, a Christian view about the market and virtues has to be sceptical about unlimited competition.

All in all, The market, happiness, and solidarity is a valuable contribution to the Christian literature about the market, and also about economics in general. Whether or not the market can be seen as a blessing from a Christian perspective depends on a lot of factors and Graafland discusses them carefully. For him, the question is not so much whether Christians should accept the market system, but rather how its harmful consequences can be diminished. The distinctive strength of the book is its emphasis on a great variety of (recent) economic research into the market, both theoretical and empirical. As noted, it does not begin from a theological point of view as is often 
the case in Christian economic literature, but combines and does justice to economics, ethics, and theology. A disadvantage of this multidisciplinary approach is that the book often arrives at rather nuanced if not too nuanced conclusions. In the final "Integration and application" chapter, for example, in which Graafland applies the findings of the book to a case study of replacing a progressive tax system by a flat-rate income tax, it appears to be hard to draw clear conclusions. More generally, the book successfully shows that all three ethical perspectives-welfare or happiness, justice, and virtueslegitimate the market and its plea against too much government regulation, but also suggest a need for limitations and a strong state to correct the market. These and other nuanced views in the book are not really surprising, but nevertheless plausible. After all, the truth is often in the middle.

\section{REFERENCES}

Graafland, Johan J. 2007a. Economics, ethics and the market: introduction and applications. London: Routledge.

Graafland, Johan J. 2007b. Het oog van de naald. Over de markt, geluk en solidariteit. Kampen: Ten Have.

Hirschman, Albert O. 1982. Rival interpretations of market society: civilizing, destructive or feeble? Journal of Economic Literature, 20 (4): 1463-1482.

Joost W. Hengstmengel graduated in economics and informatics, and is currently a research master student in philosophy and economics at the Erasmus Institute for Philosophy and Economics (EIPE), at Erasmus University Rotterdam (The Netherlands).

Contact e-mail: <joosthengstmengel@gmail.com>

Website: <http://hengstmengel.wordpress.com> 